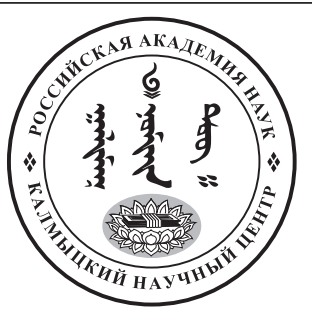

Published in the Russian Federation

Oriental Studies (Previous Name: Bulletin of the Kalmyk Institute

for Humanities of the Russian Academy of Sciences)

Has been issued as a journal since 2008

ISSN: 2619-0990; E-ISSN: 2619-1008

Vol. 13, Is. 4, pp. 916-926, 2020

DOI: $10.22162 / 2619-0990-2020-50-4-916-926$

Journal homepage: https://kigiran.elpub.ru

УДК 94 (470.57)

DOI: 10.22162/2619-0990-2020-50-4-916-926

\title{
Роль добровольных народных дружин Башкирии в противодействии росту правонарушений в 1960 - первой половине 1980-х гг.
}

\author{
Наркас Вафиевна Ахмадиева
}

${ }^{1}$ Институт истории, языка и литературы Уфимского федерального исследовательского центра РАН (д. 71, просп. Октября, 450054 Уфа, Российская Федерация) кандидат исторических наук, старший научный сотрудник iD 0000-0002-5049-6337. E-mail: ahmadieva72@mail.ru

\section{(C) КалмНЦ РАН, 2020}

(C) Ахмадиева Н. В., 2020

Аннотация. Введение. В 1960-е - середине 1980-х гг. в условиях роста преступности государство передало обществу некоторые функции охраны правопорядка и обеспечения безопасности граждан. Деятельность общественных организаций - добровольных народных дружин способствовала противодействию росту преступности и правонарушений в стране. Несмотря на наличие научных трудов по деятельности добровольных народных дружин в указанные годы в общероссийском масштабе, региональный аспект данной проблемы не получил должного освещения. Добровольные народные дружины получили дальнейшее развитие и в постсоветский период, подтверждая свою востребованность. Материалы. Основными источниками статьи послужили материалы и документы Национального архива Республики Башкортостан, которые содержат ценные сведения о деятельности добровольных народных дружин, системе мер, направленных на борьбу с ростом правонарушений. Методы исследования. Динамика развития добровольных народных дружин и качественные изменения их состава были изучены на основе историко-генетического метода. Анализ архивных документов и материалов осуществлялся на принципах объективности и историзма, позволивших рассмотреть деятельность добровольных народных дружин Башкирии 1960-х и середины 1980-х гг. во взаимосвязи со сложившейся конкретно-исторической ситуацией. Целью данного исследования является анализ деятельности добровольных народных дружин Башкирии в 1960 - первой половине 1980-х гг. Результаты. В рассматриваемые годы в Башкирии было завершено создание сети добровольных народных дружин как вспомогательной организации, призванной на борьбу с ростом преступности и правонарушений. Контролируемые властными структурами, народные дружины превратились в мощную организацию, направленную на борьбу с противоправными 
явлениями. Они воздействовали на процесс правового воспитания советских граждан. Добровольные народные дружины совместно с органами охраны общественного порядка провели существенную работу по снижению уровня правонарушений. Автор приходит к выводу, что участие рядовых граждан в охране правопорядка было продиктовано растущей криминализацией общества и имеющимися изъянами в системе охраны общественного порядка. Партийно-государственные органы были вынуждены инициировать и поддерживать добровольные народные дружины.

Ключевые слова: охрана общественного порядка, добровольные народные дружины, преступность, правонарушения, Башкирия, правоохранительные органы

Благодарность. Исследование проведено в рамках государственной субсидии - проект «Духовная культура тюркских народов Южного Урала» (номер госрегистрации: АААА-А17-117040350082-3).

Для цитирования: Ахмадиева Н. В. Роль добровольных народных дружин Башкирии в противодействии росту правонарушений в 1960 - первой половине 1980-х гг. // Oriental Studies. 2020. T. 13. № 4. C. 916-926. DOI: 10.22162/2619-0990-2020-50-4-916-926

UDC 94 (470.57)

DOI: $10.22162 / 2619-0990-2020-50-4-916-926$

\title{
Resisting the Increase of Crime, 1960s - Mid-1980s: Impact of Bashkiria-Based Voluntary People's Guards
}

\author{
Narkas V. Akhmadieva ${ }^{1}$ \\ ${ }^{1}$ Institute of History, Language and Literature of the Ufa Federal Research Centre of the RAS (71, \\ Oktyabrya Ave., Ufa 450054, Russian Federation) \\ Cand. Sc. (History), Senior Research Associate \\ iD 0000-0002-5049-6337. E-mail: phmadieva72@mail.ru
}

(C) KalmSC RAS, 2020

(C) Akhmadieva N. V., 2020

\begin{abstract}
Introduction. In the 1960s - mid-1980s, in the face of an increase in crime, the state transferred some law enforcement and domestic security functions to the public. Activities of public organizations - voluntary people's guards (Russ. DND) — contributed to countering the growth of crime and delinquency in the country. Despite the availability of scientific papers dealing with activities of the DND in the indicated years nationwide, the regional aspect of the issue remains understudied. DNDs were further developed in the post-Soviet period, which confirms their efficiency and significance. Goals. The paper seeks to analyze activities of voluntary people's guards in the 1960s - mid1980s. For this, a number of objectives be tackled, such as to consider the dynamics of their development, analyze forms of countering the growth of offenses in Bashkiria in the indicated years, state policy towards this public organization. Materials. The article primarily investigates materials and documents deposited in the National Archive of Bashkortostan which contains valuable information thereto, including about the system of measures aimed at combating the growth of offenses. Methods. The work employs the historical-genetic method which made it possible to examine the dynamics of development and structural changes in the DND. The analysis of archival documents and materials involves the principles of objectivity and historicism, and that of scientificity, which proves instrumental in exploring the topic in certain historical backgrounds. Results. The period under consideration witnessed the creation of a network of voluntary people's guards as an auxiliary organization designed to combat the growth of crime and delinquency in Bashkiria. The squads were controlled by authorities and grew to become a powerful law enforcement institution. Moreover, those facilitated further legal education of Soviet citizens. DNDs and order control agencies did prove efficient
\end{abstract}


in reducing the level of offenses. The paper concludes the involvement of ordinary citizens in law and order protection activities was determined by the then increasing criminalization of society and flaws in the order and safety system. Party and state bodies were thus forced to initiate and support the movement.

Keywords: protection of public order, voluntary people's squads (guards), crime, offenses, Bashkiria in the 1960s and mid-1980s, law enforcement agencies

Acknowlegdements. The reported study was funded by government subsidy — project name 'Turkic Peoples of the Southern Urals: Spiritual Culture' (state reg. no. AAAA-A17-117040350082-3).

For citation: Akhmadieva N. V. Resisting the Increase of Crime, 1960s - Mid-1980s: Impact of Bashkiria-Based Voluntary People's Guards. Oriental Studies. 2020. Vol. 13(4): 916-926. (In Russ.).

DOI: $10.22162 / 2619-0990-2020-50-4-916-926$

\section{है}

\section{Введение}

В начале 1960-х гг., в условиях либерализации судебно-правовой системы, правоохранительные органы не смогли взять под контроль ситуацию с усиливающейся криминализацией общества. Несмотря на систему правоохранительных мер, координируемую законодательными и нормативно-правовыми актами, темпы роста преступности в 1960-е - середине 1980-х гг. были значительными. Число осужденных в СССР только с 1967 по 1982 гг. возросло более чем в полтора раза - с 731 тыс. человек до 1 млн 148 тыс. Коэффициент судимости в расчете на 100 тыс. населения всех возрастов увеличился с 311 до 428 [ГА РФ. Ф. Р-9492. Оп. 6. Д. 402. Л. 37].

Государство было вынуждено делегировать ряд функций охраны правопорядка и обеспечения безопасности граждан общественности. В системе мер, направленных на охрану общественного порядка, значительное место отводилось деятельности добровольных народных дружин (далее - ДНД), общественных организаций, призванных противодействовать росту преступности и правонарушений.

Целью данной работы является изучение проблем развития добровольных народных дружин Башкирии и их роли в противодействии росту правонарушений в 1960-е первой половине 1980-х гг. Для раскрытия темы выделено несколько задач: проследить динамику роста и структурные изменения народных дружин; отразить специфику функционирования ДНД в системе охраны общественного порядка; изучить конкретную деятельность ДНД по предупрежде- нию правонарушений и преступлений; дать характеристику государственной политики, направленной на повышение роли общества в охране общественного порядка.

Исследование является актуальным в силу того, что обращение к историческому прошлому позволит оценить масштабы деятельности этих общественных структур, призванных ослабить криминогенную ситуацию. Добровольные народные дружины как общественное движение получили дальнейшее развитие и в постсоветский период, подтверждая свою значимость и востребованность. В работе применялся историко-генетический метод, позволивший рассмотреть динамику развития добровольных народных дружин, изменения их структуры и характеристику основных форм деятельности, отразить причинно-следственные связи и закономерности их возникновения.

Источниковую базу научной статьи составляют архивные материалы, выявленные в фондах Государственного архива Российской Федерации (ГА РФ), фонда Р-9492 Министерства юстиции СССР, а также Национального архива Республики Башкортостан (НА РБ). Значительный массив информации по изучаемой проблеме извлечен из документов и материалов Национального архива Республики Башкортостан, фонда 122 Башкирского обкома КПСС. В их числе стенограммы совещаний работников прокуратуры, суда и МВД по вопросам борьбы с преступностью в республике, справки о состоянии преступности и следственной работы; краткие справки по основным показателям работы Министерства внутренних дел Башкирской АССР. Эти источники 
предоставили обширные сведения о динамике, структуре и основной деятельности добровольных народных дружин, дали характеристику криминогенной ситуации в республике. При научном анализе архивных источников были приняты во внимание принципы объективности и историзма, необходимые для изучения проблемы с учетом сложившихся в данной ситуации исторических реалий.

Историография проблемы развития добровольных народных дружин и их роли в охране общественного порядка достаточно обширна. На общероссийском уровне она привлекла внимание правоведов и историков еще в 1960-е гг. Основная часть указанных работ была призвана ознакомить широкого читателя со спецификой деятельности дружин, основными целями и методами работы [Пертцик 1960; Байтин, Гольдман 1969; Основин, Поборчая, Труфанов 1961].

Более глубокий научный подход к изучению проблемы обозначился в 1970-1980-е гг. Несмотря на информативную и научную ценность данных трудов, исследование народных дружин строилось на принципах советской историографии, а также затруднялось недостаточной фактологической базой исследований [Соколов 1977; Борисенков, Кригер 1977; Тюрин 1981; Участие трудящихся 1986].

В постсоветский период общероссийская историография изучения ДНД пополнилась исследованиями, дающими разносторонний анализ их функционирования, результатов и перспектив деятельности. Однако региональный аспект проблемы практически не был исследован, отсутствуют исторические работы о развитии ДНД в Башкирии [Пыжиков 1999; Иванов, Бояринцева 2015; Рыбалка 2010; Евсеев 2017; Кужахметова 2020; Лосяков, Доброва 2015; Рагунштейн 2020].

\section{Роль дружин в борьбе с правонаруше- ниями}

Динамика роста численности дружсин и их деятельность в 1960-е-середине 1970-х г2.

Следует отметить, что первые добровольные народные дружины были созданы в 1958 г. на базе крупных предприятий г. Ленинграда. Власти подхватили инициирован- ную ею же «низовую инициативу», и 2 марта 1959 г. ЦК КПСС и Совет Министров СССР приняли постановление № 218 «Об участии трудящихся в охране общественного порядка в стране». В постановлении было заявлено о необходимости «принять многочисленные предложения трудящихся о создании на предприятиях, стройках, транспорте, в учреждениях, совхозах, колхозах, учебных заведениях и домоуправлениях добровольных народных дружин по охране общественного порядка» [НА РБ. Ф. 122. Оп. 47. Д. 422. Л. 38-39]. Данным постановлением было утверждено примерное положение «О добровольных народных дружинах». Партийные органы были обязаны организовывать народные добровольные дружины, районные (городские) штабы и обеспечивать их успешную деятельность по поддержанию общественного порядка в стране. Предполагалось проведение массово-разъяснительной работы среди населения по вопросу значимости данного мероприятия. Было необходимо добиться поддержки деятельности народных дружин со стороны широких слоев общества [НА РБ. Ф. 122. Оп. 47. Д. 422. Л. 67-68]. Практически до середины 1970-х гг. эти постановления и положения стали основными законодательными документами, определившими задачи, полномочия и формы организации ДНД.

Добровольные народные дружины как общественные самодеятельные организации, призванные оказывать содействие правоохранительным органам в охране общественного порядка, борьбе с преступностью, проведении воспитательной работы с населением во взаимодействии с государственно-партийными и профсоюзными органами, вели активную работу в Башкирии. За первое полугодие 1960 г. с помощью дружинников и другой общественности было предупреждено 1287 уголовных преступлений. Члены ДНД доставили в милицию свыше 1500 нарушителей общественного порядка, 840 мелких хулиганов, 616 нарушителей правил уличного движения, задержали 196 уголовных преступников [Ахмадиева 2017: 12].

Несмотря на имевшиеся положительные результаты, развитие ДНД сопровождалось рядом трудностей организационного характера, формальным отношением к обя- 
занностям, непониманием всех масштабов ответственности и задач, возлагаемых государством и обществом на эту организацию. К тому же надо учитывать тот факт, что сдержать рост преступности в начале 1960-х гг. было не под силу всей системе охраны правопорядка. В Башкирии к ежедневному патрулированию привлекалось незначительное число дружинников, которое было неспособно контролировать криминогенную ситуацию на улицах городов и сел. В 1960 г. в Уфе из 32 тыс. дружинников в среднем ежедневно несли охрану только 300-400 человек. В г. Стерлитамаке из 6 тыс. дружинников участвовало в охране около 90-100 человек [НА РБ. Ф. 122. Оп. 47. Д. 239. Л. 156].

Несмотря на то, что с 1959 г. до середины 1960-х гг. численность членов ДНД Башкирии возросла до 120 тыс. человек, рост уличных преступлений и нарушений общественного порядка в городах и районах республики не был предотвращен. В г. Ишимбае произошла активизация хулиганства, количество уголовных преступлений за 7 месяцев 1960 г. в сравнении с тем же периодом 1959 г. увеличилось почти в два раза, в том числе выросли такие опасные преступления, как разбойные нападения — в 2,5 раза, кражи - в 8 раз, нанесение тяжких телесных повреждений - в 5 раз и т. д. Дружины г. Ишимбая были формально закреплены за микрорайонами, ответственности за состояние охраны порядка не несли. Плохо работали многие дружины гг. Октябрьского, Стерлитамака, а также Бирского, Краснокамского, Альшеевского, Хайбуллинского и Белорецкого районов. Состояние общественного порядка вызывало серьезную тревогу у граждан, поскольку дружинники не могли защитить население от хулиганов и пьяниц [НА РБ. Ф. 122. Оп. 47. Д. 238. Л. 293-294].

В начале 1960-х гг. народные дружины Башкирии находились на стадии становления, еще не в полной мере были приняты во внимание их обязанности, поэтому результаты деятельности были весьма скромными. Перегруженные многочисленными функциями предприятия, организации и учреждения, из рядов которых формировались дружинники, не ставили задачи охраны правопорядка и предотвращения правонарушений в разряд приоритетных.
Примечательно, что, помимо охраны общественного порядка, добровольные народные дружины вели определенную работу, направленную на борьбу с самогоноварением в Башкирии. Так, в 1960 г. дружинники Дюртюлинского района ознакомили население с указом Президиума Верховного Совета РСФСР об ответственности за самогоноварение и приготовление других спиртных напитков в домашних условиях. В январе в райкоме КПСС стало известно о наличии в колхозе «Правда» фактов самогоноварения. Бюро райкома направило туда пропагандистскую группу из работников райкома, членов районного штаба ДНД. Ими были прочитаны доклады, проведены партийные и комсомольские собрания, собрания граждан по деревням. Проделанная работа дала свои результаты - население стало добровольно сдавать самогонные аппараты, обещая больше не заниматься «этим позорным делом» [НА РБ. Ф. 122. Оп. 47. Д. 422. Л. 83]. По району было собрано 320 самогонных аппарата [НА РБ. Ф. 122. Оп. 47. Д. 422. Л. 84].

Весьма неприятным моментом в деятельности дружин являлись случаи превышения ими допустимых полномочий в ходе борьбы с пьянством и другими нарушениями общественного порядка. В материалах Национального архива Республики Башкортостан встречаются документы, в которых прокуратурой и обкомом КПСС рассматривались случаи нанесения дружинниками тяжких телесных повреждений, произошедших при попытке задержания нетрезвых, агрессивных, оказывающих сопротивление граждан. Подобное жесткое силовое давление на хулиганов, нарушителей общественного порядка, на наш взгляд, не порицалось, a, скорее, поощрялось правоохранительными органами. Так, в Уфе в 1964 г. задержанному «пьяному дебоширу», избивавшему жену, дружинники нанесли несколько ударов. Впоследствии он был избит резиновой дубинкой в милиции, из-за полученных травм скончался в больнице [НА РБ. Ф. 122. Оп. 74. Д. 319. Л. 10-15; 64-65].

В сложных условиях борьбы с правонарушениями подобные инциденты имели место, формируя негативное отношение общественности к дружинникам и правоохранительным органам. 


\section{Развитие ДНД в 1975 - начале 1980-х г2.}

К середине 1970-х гг. произошли существенные изменения в составе ДНД. Возникла необходимость более четкого структурирования и направления деятельности дружин по определенным сферам правонарушений и преступлений (дорожно-транспортных, экономических правонарушений, уличной, бытовой преступности и т. п.). В качестве самостоятельных подразделений были выделены территориальные и специализированные отряды дружин. Территориальные дружины, созданные на базе предприятий и учреждений, поддерживали охрану общественного порядка на определенной, закрепленной за ними территории. Выполняя постановление ЦК КПСС и Совета Министров СССР от 20 апреля 1974 г. «О дальнейшем совершенствовании деятельности добровольных народных дружин по охране общественного порядка» в Башкирии также стали создаваться специализированные дружины. Они были направлены на противодействие различным видам правонарушений. К началу 1975 г. с участием 678 специализированных дружин было выявлено 258 фактов хищений, задержано более 11 тыс. нарушителей правил дорожного движения [НА РБ. Ф. 122. Оп. 215. Д. 244. Л. 19].

В 2,5 раза увеличилось число дружинников, участвующих в индивидуально-воспитательной работе, число ведущих профилактическую работу по предотвращению правонарушений среди несовершеннолетних возросло в 3 раза. В том же году в охране общественного порядка в республике участвовали 3487 ДНД, в которых насчитывалось более 160 тыс. дружинников. Для руководства ими назначались опытные и авторитетные представители партийно-хозяйственной номенклатуры. В первом полугодии 1975 г. на улицах и в других общественных местах с участием дружинников было пресечено 45 преступлений, раскрыто 342 преступления, выявлено 8907 нарушителей общественного порядка [НА РБ. Ф. 122. Оп. 215. Д. 244. Л. 20-21].

В городах и районных центрах Башкирии имелись опорные пункты милиции, при которых находились штабы и группы ДНД. В рядах дружинников было немало активистов, отдававших много сил на борьбу с преступностью.
Со второй половины 1970-х гг. контроль над деятельностью ДНД со стороны правоохранительных органов становится более тщательным. МВД БАССР был разработан комплекс мер по охране общественного порядка, координирующий взаимодействие органов внутренних дел с народными дружинами. В управлениях и отделах Министерства, горрайорганах внутренних дел было выделено 355 работников для организации повседневного взаимодействия милиции с ДНД, из них 55 с освобождением от других обязанностей. Органами прокуратуры, суда и горрайотделов внутренних дел совместно с городскими и районными штабами ДНД организовывалось изучение дружинниками основ советского законодательства [НА РБ. Ф. 122. Оп. 215. Д. 244. Л. 21]. Взаимодействие народных дружин Башкирии с органами внутренних дел и прокуратуры в борьбе с антиобщественными проявлениями значительно усилилось.

В 1980-е гг. в Башкирии продолжилась работа по совершенствованию деятельности добровольных дружин в охране общественного порядка, более полному и эффективному использованию сил и средств для укрепления патрульно-постовой службы, улучшения взаимодействия добровольных народных дружин с милицией. Партийно-руководящими органами республики были разработаны и утверждены планы мероприятий по выполнению постановления ЦК КПСС от 2 августа 1979 г. «Об улучшении работы по охране правопорядка и усилении борьбы с правонарушениями» на 1980 г.

В первом полугодии 1980 г. в дружинах предприятий, учреждений, строек, колхозов и совхозов проводились собрания дружинников, а в городах и районах - слеты и активы, где обсуждались итоги деятельности ДНД и задачи на очередной год. Республиканский штаб и МВД БАССР осуществляли контроль над ежедневным выходом дружинников на охрану общественного порядка в 16 городах республики [НА РБ. Ф. 122. Оп. 215. Д. 244. Л. 72].

Определенное внимание уделялось вопросам правового обучения членов народных дружин. В 1980 г. на факультетах правовых знаний при народных университетах занимались более 20 тыс. дружинников, в лекториях и школах - около 100 тыс. человек. Штабом ДНД и МВД БАССР прини- 
мались меры к оказанию помощи нижестоящим штабам путем разработки и направления им инструкций и рекомендаций в различные периоды хозяйственной деятельности в селах, районах и городах (весенний сев, сенокос, уборка урожая и т. д.). Также были изготовлены и направлены в города и районы Башкирии 50 тыс. удостоверений дружинника [НА РБ. Ф. 122. Оп. 215. Д. 244. Л. 73].

Рассмотрение специфики форм взаимодействия государственных и правоохранительных органов и добровольных народных дружин в сфере охраны правопорядка показывает, что государство рассматривало ДНД как вспомогательную, подконтрольную милиции организацию. Это ограничивало уровень ее самостоятельности, что способствовало процессу ее «огосударствления», лишая стимулов внутреннего развития, роста общественной инициативы.

Меры морального и материального поощрения членов народных дружин были призваны активизировать и качественно улучшить деятельность этих организаций. Активные дружинники награждались почетными грамотами, ценными подарками, благодарностями и денежными премиями, также дополнительными оплачиваемыми отпусками сроком до трех суток в год.

В 1974 г. вышел указ Президиума Верховного Совета СССР «Об основных обязанностях и правах ДНД по охране общественного порядка». Дружинники имели преимущество перед остальными гражданами на получение жилой площади, льготной путевки в санатории, дома отдыха. В Башкирии только в 1979 г. 20 дружинников были награждены медалью «За отличную службу по охране общественного порядка», 7 - почетными грамотами МВД СССР, 4 - ценными подарками МВД СССР, 145 - значком «Отличный дружинник», 60 - почетными грамотами МВД БАССР. Большое число дружинников было поощрено дополнительными отпусками [НА РБ. Ф. 122. Оп. 215. Д. 244. Л. 70].

В 1980 г. 216 дружинников были награждены знаком «Отличный дружинник», 128 - почетными грамотами МВД БАССР, многие члены ДНД были также получили дополнительные отпуска [НА РБ. Ф. 122. Оп. 215. Д. 244. Л. 74]. Однако, несмотря на все меры поощрения со стороны госу- дарственных органов, для многих рядовых граждан участие в работе дружин становилось «обязаловкой», обременительным и небезопасным времяпрепровождением.

Постоянное принудительное участие граждан в работе народных дружин приводили к пассивному, формальному участию людей в охране общественного порядка. Применение властью рычагов административного давления на население снижало градус общественной активности. Поэтому для пропаганды лучшего опыта работы народных дружин широко использовались возможности радио, телевидения печати. Только в 1979 г. на эти темы было организовано 19 телепередач, 26 радиобесед, в республиканских газетах и в местной печати опубликовано более 2 тыс. статей [НА РБ. Ф. 122. Оп. 215. Д. 244. Л. 70].

В 1980 г. аналогично проведено 12 телепередач, 18 радиобесед, в республиканских газетах и в местной печати опубликовали 818 статей по проблемам развития этих организаций. Несмотря на широкую пропаганду деятельности дружин, в их работе наблюдались существенные недостатки. В отдельных городах и районах не выполнялись обязательные нормы выхода дружинников на охрану общественного порядка. В ряде городов и районов норма выхода составляла от 20 до 78 \%, при достаточно высокой среднереспубликанской - 91,0 \% [НА РБ. Ф. 122. Оп. 215. Д. 244. Л. 74].

Несмотря на имеющиеся в деле развития организации противоречия и сложности, роль добровольных народных дружин в борьбе с ростом правонарушений была весьма значительной. ДНД стали важной частью системы охраны общественного порядка. В Башкирии в 1978 г. с их участием было раскрыто 1118 преступлений, в 1979 г. - 1220 преступлений. Задержано правонарушителей соответственно 3408 и 3 745, предотвращено преступлений - 25 и 24 [НА РБ. Ф. 122. ОП. 200. Д. 414. Л. 5].

За 1979 г. было вновь создано 105 дружин, и общее их число достигло 4,6 тыс. с охватом 210,8 тыс. человек. В целом по республике в охране общественного порядка ежесуточно участвовало 6,5 тыс. дружинников, что составляло 17 чел. на 10 тысяч населения. В целях улучшения противодействия росту отдельных видов правонарушений в Башкирии функционировало 1996 специа- 
лизированных дружин, с охватом 25 тыс. дружинников. В их числе имелось 311 дружин по борьбе с хищениями социалистической собственности, 1351 организация по обеспечению безопасности дорожного движения, 196 дружин по борьбе с пьянством и нарушениями правил торговли спиртными напитками и 518 - по предупреждению правонарушений среди несовершеннолетних [НА РБ. Ф. 122. Оп. 215. Д. 244. Л. 69].

В первом полугодии 1980 г. с участием дружинников было раскрыто 1190 преступлений (+4,1%), задержано 24369 нарушителей общественного порядка $(+32,7 \%)$. В республике действовали 2376 специализированных дружин по линии БХСС, ГАИ, по предупреждению правонарушений среди несовершеннолетних, на почве пьянства и другие. Спецдружины объединяли более 25 тыс. человек. Подавляющее большинство (88,0 \%) дружинников принимали непосредственное участие в охране общественного порядка. В первом квартале 1980 г. повсеместно на предприятиях, в учреждениях, колхозах и совхозах проводились собрания дружинников, в городах и районах - слеты и активы дружинников, 21 июня состоялся республиканский слет добровольных народных дружин. Согласно принятому решению Республиканского штаба ДНД, проводилась работа по созданию специализированных дружин из работников общественного транспорта. МВД были внесены предложения в СМ БАССР по оснащению техническими средствами общественного транспорта городов Уфы, Салавата, Стерлитамака. Примечательно, что по опыту Горьковского завода «Красное Сормово» и Львовской железной дороги предусматривалось создание специализированных народных дружин по охране общественного порядка в пригородных поездах, железнодорожных станциях силами коллективов предприятий [НА РБ. Ф. 122. Оп. 200. Д. 413. Л. 15-18]. Пригородные электрички и железнодорожные станции являлись активными криминогенными зонами, особенно в темное время суток. Решение об их патрулировании дружинами было вызвано крайней необходимостью, в связи с ростом совершенных там преступлений.

Проведенная работа способствовала организационному укреплению дружин, повышению качественного состава и эффек- тивности их работы. За 1980 г. общее число ДНД достигло 4612 с охватом 210,8 тыс. дружинников. В городах и районах в охране общественного порядка ежесуточно участвовали 2800 человек, что составляло около 20 дружинников на 10 тысяч населения.

В целях лучшей организации работы по борьбе с отдельными видами правонарушений в республике действовали 2026 специализированных дружин с охватом 35 тыс. дружинников. В их числе - 311 дружин по борьбе с хищениями социалистической собственности, 857 дружин по обеспечению безопасности дорожного движения, 170 дружин по борьбе с пьянством и нарушениями правил торговли спиртными напитками и 688 - по предупреждению правонарушений среди несовершеннолетних. В республике функционировал 981 общественный пункт охраны порядка, за которыми были закреплены 1990 дружин с числом 135 тыс. дружинников [НА РБ. Ф. 122. Оп. 215. Д. 244. Л. 73].

В конце 1970 - начале 1980-х гг., в связи с ростом экономических преступлений, многие дружинники входили в группы народного контроля, нацеленные на борьбу с коррупцией и хищениями соцсобственности.

В 1980 г. с участием дружинников было раскрыто 2,4 тыс. преступлений, задержано 48,9 тыс. правонарушителей. Активно работали дружины Октябрьского и Советского районов г. Уфы, городов Белебея, Нефтекамска, Салавата, Сибая, Стерлитамака, Туймазы, а также Балтачевского, Дюртюлинского, Зианчуринского, Краснокамского, Чишминского районов. В дни подготовки и проведения XXII Олимпийских игр в Москве, когда значительные силы патрульно-постовой службы милиции Уфы были направлены в столицу, большую роль в охране общественного порядка играли народные дружины города [НА РБ. Ф. 122. Оп. 215. Д. 244. Л. 74].

На начало 1984 г. в республике действовало 4612 ДНД, с числом дружинников 245400 человек. Ежедневно в 1983 г. в охране общественного порядка принимало участие 6995 дружинников, или 18 человек в расчете на 10 тысяч населения. С их участием было предупреждено 32 преступления и задержано 2806 преступников, что на 34,2 \% больше, чем за аналогичный период 1982 г. [НА РБ. Ф. 122. Оп. 215. Д. 244. Л. 114]. 
Особое значение в деятельности дружин придавалось вопросу профилактики роста правонарушений среди населения, которая заключалась, в том числе, в выявлении алкоголиков, тунеядцев, с целью попытки вовлечения их активную социальную жизнь, путем устройства на работу, принудительного лечения от алкоголизма и т. п. Для предотвращения роста преступлений с применением огнестрельного оружия (в основном охотничьих ружей) оно изымалось в массовом порядке у этих «неблагонадежных» граждан.

В соответствии с требованиями указа Президиума ВС РСФСР от 28 июня 1976 г. «Об ответственности за нарушение правил приобретения, регистрации, использования и хранения огнестрельного оружия», с помощью внештатных сотрудников милиции, членов ДНД и общественности было выявлено и изъято у населения 512 стволов охотничьих ружей, в том числе у лиц, уклонявшихся от регистрации, систематически нарушавших общественный порядок, злоупотреблявших спиртными напитками. Проводимая работа позволила снизить количество преступлений, совершаемых с применением огнестрельного оружия. Тем не менее, за 5 месяцев 1979 г. было совершено 28 таких преступлений, в том числе из нарезного оружия - 2, из гладкоствольного 26. В 1978 г. за тот же период было совершено 25 преступлений. МВД республики совместно с ДНД проводили мероприятия по дополнительному выявлению лиц, имеющих незарегистрированное огнестрельное оружие, и по его изъятию [НА РБ. Ф. 122. Оп. 215. Д. 247. Л. 125].

Выполняя требования Президиума Верховного Совета СССР от 11 мая 1983 г. и постановления ВС БАССР от 9 июня 1983 г. «О работе Советов народных депутатов республики среди населения по месту жительства», милицией совместно с ДНД и другой общественностью проводились комплексные профилактические меропрития по предупреждению правонарушений в сфере быта, усилению борьбы с пьянством, хулиганством, тунеядством. Было выявлено и поставлено на учет 7900 лиц, допускавших правонарушения в быту, 7752 - злоупотреблявших спиртными напитками и нарушавших общественный порядок по месту жительства, с ними проводилась про- филактическая работа. У лиц, злоупотреблявших спиртными напитками и нарушавших общественный порядок, было изъято 1945 стволов огнестрельного оружия, 1670 стволов граждане сдали добровольно [НА РБ. Ф. 122. Оп. 215. Д. 245. Л. 54]. Противодействие получившим широкое распространение в обществе девиантным формам поведения граждан - хулиганству, пьянству и т. п. - стало приоритетной задачей народных дружин.

\section{Заключение}

Участие рядовых граждан в охране правопорядка было продиктовано растущей криминализацией общества и имеющимися изъянами в системе охраны общественного порядка, вследствие чего власти были вынуждены инициировать и поддерживать это «народное движение». В рассматриваемые годы в Башкирии было завершено создание сети добровольных народных дружин как вспомогательной организации, призванной на борьбу с ростом правонарушений.

Динамика численности добровольных народных дружин заметно коррелировала с увеличением масштабов преступности, правонарушений и других девиантных отклонений в стране. К концу рассматриваемого периода ДНД представляли значительную долю в структуре общественных организаций, что свидетельствовало скорее о негативных явлениях в советском социуме, нежели о высоком уровне его самоорганизации. Активное участие в деятельности дружин отнимало у членов этой организации много времени и сил, в ущерб личным интересам и потребностям. Правоохранительные органы, милиция демонстрировали неспособность контролировать процессы разрастания криминогенной ситуации в стране, переложив часть ответственности на общество.

Курируемые властными структурами, ДНД превратились в мощную организацию, направленную на борьбу с противоправными явлениями, оказывая общественное воздействие на процесс правового воспитания советских граждан. Народные дружины совместно с органами охраны правопорядка проделали существенную работу по снижению уровня преступности и правонарушений, стали важной составляющей системы охраны общественного порядка. 


\section{Источники}

ГА РФ - Государственный архив Российской Федерации.

НА РБ - Национальный архив Республики Башкортостан.

\section{Литература}

Ахмадиева 2017 - Ахмадиева Н. В. Общая характеристика и динамика преступности в 1960-е гг. // Социальные девиации в советском обществе: региональный аспект (на примере Башкирской АССР 1960-х - начала 1980-х гг.): сб. ст. Уфа: ИИЯЛ УНЦ РАН, 2017. C. 6-28.

Байтин, Гольдман 1969 - Байтин М. И., Гольдман В. С. Народные дружины. Саратов: Приволжск. кн. изд-во, 1969. 207 с.

Борисенков, Кригер 1977 - Борисенков В. Г., Кригер В. И. Руководство партийных и советских органов народными дружинами. М.: Юрид. лит-ра, 1977. 78 с.

Евсеев 2017 - Евсеев Е. А. Периоды становления и развития добровольных народных дружин как основной формы участия населения Кемеровской области в охране общественного порядка (1959-1990 гг.) // Право и образование. 2017. № 3. С. 125-130.

Иванов, Бояринцева 2015 - Иванов В. А., Бояринцева И. А. О добровольных народных дружинах и роли партии в организации их деятельности (конец 1950-х - середина 1980-х годов) // Вестник Чувашского университета. 2015. № 2. С. 49-55.

Кужахметова 2020 - Кужахметова C. Н. Coвершенствование организации и деятельности добровольных народных дружин (конец 1950-х - середина 1970-х годов) // Юридическая наука в XXI веке: актуальные проблемы и перспективы их решений. Сб. науч. ст. по итогам работы третьего круглого стола со всерос. и междунар. участием (г. Шахты, 30-31 марта 2020 г). Шахты: ООО «Конверт», 2020. С. 105-106.

\section{References}

Akhmadieva N. V. Criminal situation, 1960s: general characteristics and dynamics. In: Akhmadieva N. V. (ed.) Social Deviations of Soviet Society in a Regional Perspective: A Case Study of the Bashkir ASSR, 1960s - early 1980s. Collected Papers. Ufa: Institute of History, Language and History (Ufa Federal Research Centre of RAS), 2017. Pp. 6-28. (In Russ.)

\section{Sources}

National Archive of the Republic of Bashkortostan State Archive of the Russian Federation

Лосяков, Доброва 2015 - Лосяков А. В., Доброва О. В. История становления и развития добровольных народных дружин в Пензенской области в 1959-1961 гг. // XXI век: итоги прошлого и проблемы настоящего плюс. 2015. T. 3. № 6 (28). С. 192-195.

Основин, Поборчая, Труфанов 1961 - Основин В., Поборчая Н., Труфанов В. На страже общественного порядка. М.: Госюриздат, $1961.58 \mathrm{c}$.

Пертцик 1960 - Пертциик B. А. Народные дружины. Иркутск: Кн. изд-во, 1960. 92 с.

Пыжиков 1999 - Пыжиков А. В. Государственное строительство и правоохранительная система СССР в 1953-64 гг. М.: Социум, 1999. $127 \mathrm{c}$.

Рагунштейн 2020 - Рагунштейн А. Г. Правовой статус добровольных народных дружин по охране общественного порядка (1959-1991 годы) // Историко-правовые проблемы: новый ракурс. 2020. № 1. С. 121-133.

Рыбалка 2010 - Рыбалка О. В. Общественная активность в СССР в начале 1960-х - второй половине 1970-х: формирование и развитие добровольных народных дружин (на материалах Новгорода и Новгородской области): дис. ... канд. ист. наук. СПб., 2010. 182 с.

Соколов 1977 - Соколов И. В. Добровольные народные дружины по охране общественного порядка. М.: Юрид. лит-ра, 1977. 78 с.

Тюрин 1981 - Тюрин В. E. Народные дружины на страже общественного порядка. Алма-Ата: Казахстан, 1981. 39 с.

Участие трудящихся 1986 - Участие трудящихся в охране общественного порядка. М.: Академия МВД СССР, 1986. 146 с.

Baytin M. I., Goldman V. S. People's Volunteer Squads. Saratov: Volga Book Publ., 1969. 207 p. (In Russ.)

Borisenkov V. G., Kriger V. I. Party and Soviet Agencies: Administering People's Volunteer Squads. Moscow: Yuridicheskaya Literatura, 1977. 78 p. (In Russ.)

Evseev E. A. Periods of formation and development of voluntary national teams as the main form of 
participation of the population of the Kemerovo Region in the maintenance of public order (1959-1990). Law and Education. 2017. No. 3. Pp. 125-130. (In Russ.)

Ivanov V. A., Boyarintseva I. A. On voluntary people's guards and the role of the Party in organizing their activities (late 1950s - mid 1980s). Vestnik Chuvashskogo universiteta. 2015. No. 2. Pp. 49-55. (In Russ.)

Kuzhakhmetova S. N. Improving the administration of people's volunteer squads: late 1950 s - mid1970s. In: Science of Law in the $21^{\text {st }}$ Century. Topical Issues and Supposed Solutions. Round Table Reports (Shakhty; March 30-31, 2020). Shakhty: Konvert, 2020. Pp. 105-106. (In Russ.)

Losyakov A. V., Dobrova O. V. The history of formation and development of voluntary national teams in Penza Region in 19591961. XXI Century: Resumes of the Past and Challenges of the Present plus. 2015. Vol. 3. No. 6 (28). Pp. 192-195. (In Russ.)

Osnovin V., Poborchaya N., Trufanov V. Guarding Public Order. Moscow: Gosyurizdat, 1961. 58 p. (In Russ.)
Participation of Laborers in the Defense of Public Order. Moscow: Academy of USSR Ministry of Internal Affairs, 1986. 146 p. (In Russ.)

Perttsik V. A. People's Volunteer Squads. Irkutsk: Irkutsk Book Publ., 1960. 92 p. (In Russ.)

Pyzhikov A. V. Soviet State-Building, and Law Enforcement System: 1953 - 1964. Moscow: Sotsium, 1999. 127 p. (In Russ.)

Ragunshteyn A. G. Legal status of the voluntary people's druzhina for the protection of public order (1959-1991). Historical-Legal Problems: the New Viewpoint. 2020. No. 1. Pp. 121-133. (In Russ.)

Rybalka O. V. Social Activities in the USSR, Early 1960s - Late 1970s: The Shaping and Development of People's Volunteer Squads. A Case Study of Novgorod City and Novgorod Oblast. Cand. Sc. (history) thesis. St. Petersburg, 2010. 182 p. (In Russ.)

Sokolov I. V. Guarding Public Order: People's Volunteer Squads. Moscow: Yuridicheskaya Literatura, 1977. 78 p. (In Russ.)

Tyurin V. E. Watching Public Order: People's Volunteer Squads. Alma-Ata: Kazakhstan, 1981.39 p. (In Russ.) 